\section{Mycobacterium tuberculosis and Mycobacterium bovis derived proteins induce caspase-independent apoptosis in bovine macrophages}

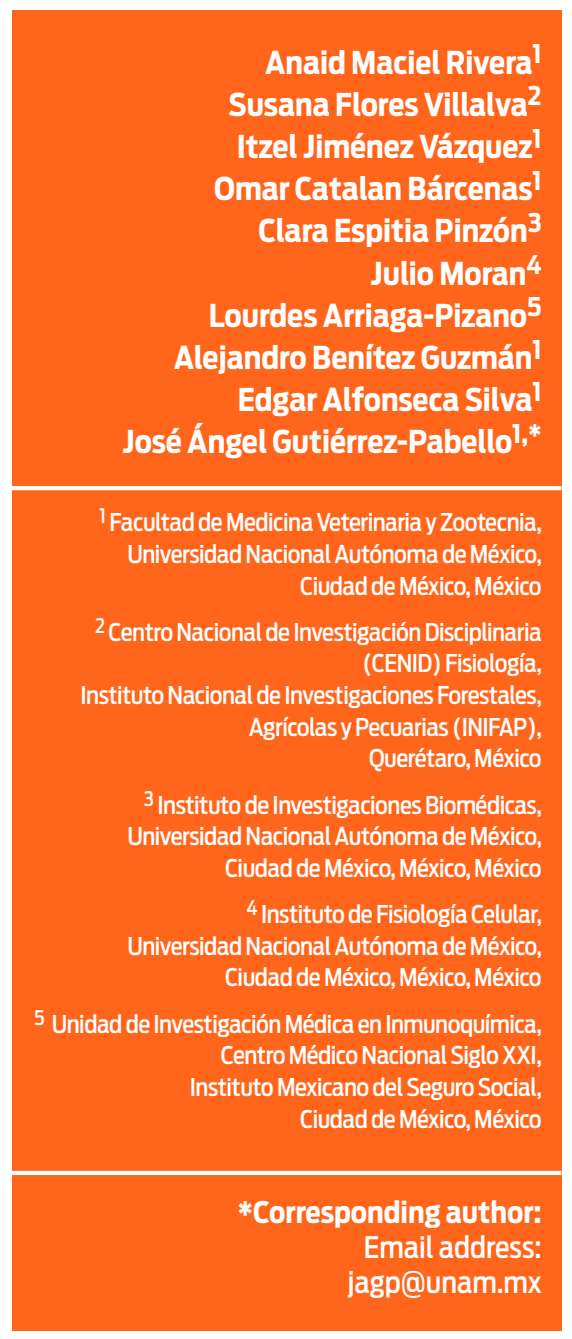

Accepted: 2018-12-13 Published: $2019-03-22$

@) Copyright 2019 Anaid Maciel Rivera et al.

open access $\boldsymbol{\gamma}$

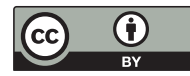

Distributed under Creative Commons CC-BY 4.0

\section{Abstract}

Species of the genus Mycobacterium are capable of inducing cell apoptosis. Infected cells with $M$. tuberculosis undergo apoptosis through a caspase-dependent pathway. We have previously shown that whole Mycobacterium bovis cells and derived crude protein extracts were able to trigger apoptosis through a caspase independent mechanism. However, the identity of the protein or protein fractions capable of inducing apoptosis has not been determined. In this study, bovine macrophages were incubated in the presence of Mycobacterium tuberculosis recombinant proteins and Mycobacterium bovis protein extracts to identify proteins capable of inducing apoptosis. A subgroup of proteins and protein extracts from strains of the Mycobacterium tuberculosis complex were shown to induce DNA fragmentation in bovine macrophages through a caspase independent pathway. Our findings suggest that bovine macrophages may elicit a different response to mycobacterium infection than that displayed by murine or human cells.

Keywords: Apoptosis, M. bovis, M. tuberculosis, Bovine macrophages, Caspase.

\section{Cite this as:}

Maciel-Rivera A, Flores-Villalva S, Jímenez-Vázquez I, Catalán-Barcenas O, Espitia-Pinzón Cl, Morán J, Arriaga-Pizano L, Benítez-Guzmán A, Alfonseca-Silva E, Gutiérrez-Pabello JA. Mycobacterium tuberculosis and Mycobacterium bovis derived proteins induce caspaseindependent apoptosis in bovine macrophages. Veterinaria México OA. 2019;6(1). doi: 10.22201/fmvz.24486760e.2019.1.560. 


\section{Introduction}

Tuberculosis is responsible for the deaths of millions of people each year and is the second leading cause of death due to an infectious disease after the human immunodeficiency virus (HIV). Human tuberculosis is mainly caused by Mycobacterium tuberculosis (M. tuberculosis), however, between 3 and 10\% of cases are due to Mycobacterium bovis (M. bovis), the etiological agent of bovine tuberculosis. ${ }^{1}$ In addition to the potential risks for human health, $M$. bovis generates enormous economic losses in the cattle industry globally. ${ }^{2}$

Pathogenesis of mycobacteria relates to their ability to survive inside host cells, especially in immune cells such as macrophages and monocytes. ${ }^{3}$ In fact, mycobacteria can disrupt the activation and phagocytic processes of immune cells. ${ }^{4}$ Species from the M. tuberculosis complex (MTC) can, for instance, survive in macrophages by inhibiting acidification of the phagosomal compartment thereby preventing the phagosome-lysosome fusion; thus not only adapting to the intracellular environment of the macrophage, but turning it into their replication niche. ${ }^{5}$

Macrophage response to MTC infection mediates the adaptive immune defense mechanisms, thus playing a central role in the outcome of the disease. ${ }^{6}$ Intracellular pathogens can induce activation of cell death mechanisms, such as apoptosis. ${ }^{7}$ During apoptosis, a cell undergoes volume reduction, rupture and condensation of chromatin, and formation of apoptotic bodies, which are vesicles created by cell membrane blebbing, that express elimination signals on their surface. Apoptotic bodies are avidly recognized and phagocytosed by professional phagocytes in a process called efferocytosis. ${ }^{8}$ Apoptosis is intracellularly directed through a biochemical cascade that activates a group of enzymes called caspases. ${ }^{9}$ These enzymes can be activated through an intrinsic pathway (i.e. mitochondrial) and an extrinsic pathway (i.e. death receptor), both of which converge to a common terminal or execution pathway, with caspase 3 as the main effector. ${ }^{8}$ However, apoptosis can also occur in the absence of caspase activation. ${ }^{10}$

Apoptosis of infected cells may benefit the host, as it removes the intracellular niche for pathogen replication. However, apoptosis can also benefit the pathogen by eliminating host defense cells, hence allowing penetration of epithelial barriers and favoring spread of infection by efferocytosis. ${ }^{11}$ When attenuated strains of $M$. bovis or M. tuberculosis (such as strains BCG or H37Ra respectively), are studied, apoptosis seems to improve control of the infection by reducing pathogen survival and limiting its intracellular growth. In contrast, virulent strains of $M$. tuberculosis decrease or inhibit apoptosis in infected human derived macrophages. ${ }^{12}$ Previous studies by our group have shown that apoptosis induction in bovine macrophages by $M$. bovis is time and dose dependent ${ }^{13}$ and does not entail activation of caspases. ${ }^{14}$ Moreover, we have established that apoptosis can also be induced by a crude protein extract from M. bovis. ${ }^{14}$ However, the identity of the protein or protein fraction capable of inducing apoptosis has not been determined. Therefore, the aim of this study was to identify Mycobacterium derived proteins capable of inducing apoptosis, through assessing the effect of Mycobacterium tuberculosis recombinant proteins and Mycobacterium bovis protein extracts on bovine macrophage cultures. 


\section{Material and methods} Bacteria

A M. bovis AN5 reference strain, donated by Dr. Rogelio Hernández-Pando of the National Institute of Medical Sciences and Nutrition, was used. Bacteria were incubated for 8 weeks in Sauton medium enriched with 0.5\% glycerol (as sole carbon source) and $4 \mathrm{~g} / \mathrm{L}$ of L-asparagine (as sole amino acid source), at $37^{\circ} \mathrm{C}$ without shaking. These culture conditions provided the greatest amount of proteins produced with minimal breakdown.

\section{M. bovis protein extracts}

The bacterial biomass from the $M$. bovis culture was filtered eight weeks after incubation using 0.45 and $0.22 \mu \mathrm{m}$ pore membranes (Merk, Millipore, MA). The culture filtrate extract (CFE) was then precipitated with $0.5 \mathrm{~g} / \mathrm{ml}$ of ammonium sulfate at $70 \%$ saturation and stirred for 24 hours at $4{ }^{\circ} \mathrm{C}$. Proteins were subsequently obtained by centrifugation at 10,300 $\times \mathrm{g}$ for 30 minutes and then dialyzed for 4 days using a 3,500 MWCO membrane (Spectra/Por).

The $M$. bovis biomass was resuspended in 1 X PBS and sonicated at $71.25 \mathrm{~W}$ in ice for 2 hours, with 5-minute pulses, followed by a one-minute rest (Virtis $\left.{ }^{\top M}\right)$. The total extract was then centrifuged at 10,000 $\times \mathrm{g}$ for 15 minutes and the supernatant (soluble extract, SE), recovered.

Total proteins from both extracts (SE and CFE), were quantified in a microplate using the bicinchoninic acid technique (Micro BCA Pierce ${ }^{\mathrm{TM}}$ ). Proteins from a single sample of each extract were also resolved by SDS-PAGE at 12\% and stained with Coomassie brilliant blue R-250.

\section{M. tuberculosis recombinant proteins}

M. tuberculosis recombinant proteins employed in this study have $99-100 \%$ of identity with their orthologous genes in M. bovis (Table 1).

\section{Bovine peripheral blood monocytes}

Macrophages derived from bovine monocytes were obtained by jugular puncture of a healthy adult donor from a tuberculosis free herd (not vaccinated, exposed or challenged), according to a method previously described by our laboratory. ${ }^{10,13,14}$ Only one donor was used to avoid individual variations in the in vitro experiments. Briefly, blood was collected in $60 \mathrm{ml}$ syringes, pre-loaded with $8 \mathrm{ml}$ of ACD. The leukocyte pack was subsequently obtained by centrifugation at $500 \times \mathrm{g}$ for $30 \mathrm{~min}$ utes, diluted 1:1 with a phosphate plus citrate solution, and placed in a 2:1 Percoll gradient (GE Healthcare Bio-Sciences AB) with a specific density of 1.077. It was thencentrifuged again at $1200 \times \mathrm{g}$ for 30 minutes, the leukocyte interface recovered and then washed on two occasions with a solution of $45 \mathrm{ml}$ phosphates plus citrate with added autologous plasma (30 $\mathrm{ml}$ and $15 \mathrm{ml}$, respectively). Finally, the cell pellet was resuspended in RPMI-1640 medium (Gibco ${ }^{\circledR}$ Cell Culture) with 4\% of autologous serum to facilitate monocyte adhesion to the Teflon bottom Erlenmeyer flasks. After being seeded into flasks, monocytes were incubated for 24 hours at $37{ }^{\circ} \mathrm{C}$ with a humid atmosphere and $5 \% \mathrm{CO}_{2}$. Unbound cells were then removed 
Table 1. Recombinant proteins used for apoptosis induction in bovine macrophages

\begin{tabular}{|c|c|c|c|c|c|}
\hline Gene & Synonymy & $\begin{array}{l}\text { Access No. Mtb/Mb } \\
\text { (Identity \%)* }\end{array}$ & $\begin{array}{l}\text { Weight } \\
\text { (kDa) }\end{array}$ & Function & Apoptosis \\
\hline dnaK & hsp70 & $\begin{array}{c}\text { Rv0350/Mb0358 } \\
(100 \%)\end{array}$ & 66.83 & $\begin{array}{c}\text { Intracellular cytoplasmic } \\
\text { chaperone. Possible ATPase activity. }\end{array}$ & NA \\
\hline $\operatorname{gln} A 1$ & $g \ln A$ & $\begin{array}{c}\text { Rv2220/Mb2244 } \\
(100 \%)\end{array}$ & 53.53 & Glutamin-synthetase & NA \\
\hline \multirow[t]{3}{*}{ PE_PGRS33 } & - & $\begin{array}{c}\text { Rv1818c/Mb1849c } \\
(99 \%)\end{array}$ & 40.75 & $\begin{array}{l}\text { Unknown function. It seems to } \\
\text { influence surface interactions. }\end{array}$ & $\begin{array}{c}\text { Caspase-dependent } \\
\text { apoptosis in murine cells }{ }^{19}\end{array}$ \\
\hline & dPGRS33 & - & - & - & - \\
\hline & dPE & - & - & - & - \\
\hline mce2A & mce2 & $\begin{array}{l}\text { Rv0589/Mb0604 } \\
\text { (99\%) }\end{array}$ & 43.45 & Invasine. & NA \\
\hline pstS 1 & $\begin{array}{l}\text { phos1, } \\
\text { phos, } \\
\text { Ag-38kDa }\end{array}$ & $\begin{array}{l}\text { Rv0934/Mb0959 } \\
(100 \%)\end{array}$ & 38.21 & Lipoprotein of unknown function. & $\begin{array}{l}\text { Caspase-dependent } \\
\text { apoptosis in human } \\
\text { MDMs }^{20}\end{array}$ \\
\hline $\mathrm{fbpB}$ & $\begin{array}{l}\text { Ag85-B, } \\
\text { mpt59 85B }\end{array}$ & $\begin{array}{c}\text { Rv 1886c/Mb } 1918 c \\
(100 \%)\end{array}$ & 34.58 & Micolyl-transferase & NA \\
\hline Apa & $\begin{array}{l}\text { Mpt32, } \\
\text { modD }\end{array}$ & $\begin{array}{c}\text { Rv1860/Mb } 1891 \\
(99 \%)\end{array}$ & 32.72 & Fibronectin binding glycoprotein. & NA \\
\hline IprG & P27 & $\begin{array}{c}\text { Rv1411c/Mb1446c } \\
(100 \%)\end{array}$ & 24.54 & Lipoprotein of unknown function. & NA \\
\hline $\operatorname{sig} \mathrm{D}$ & - & $\begin{array}{c}\text { Rv3414c/Mb3448c } \\
(100 \%)\end{array}$ & 22.91 & Probable alternative sigma factor & NA \\
\hline hbhA & - & $\begin{array}{l}\text { Rv0475/Mb0485 } \\
(100 \%)\end{array}$ & 21.53 & $\begin{array}{l}\text { Methylated protein with heparin } \\
\text { binding and sulfate dextran. }\end{array}$ & $\begin{array}{l}\text { Caspase-dependent } \\
\text { apoptosis in murine and } \\
\text { human macrophages }\end{array}$ \\
\hline hspX & Acr & $\begin{array}{l}\text { Rv2031c/Mb2057c } \\
(100 \%)\end{array}$ & 16.22 & Alpha-crystalline & $N A$ \\
\hline $\mathrm{lpqH}$ & P-19kDa & $\begin{array}{c}\text { Rv3763/Mb3789 } \\
(100 \%)\end{array}$ & 15.11 & $\begin{array}{l}\text { Lipoprotein secreted and } \\
\text { associated with the cell wall. }\end{array}$ & $\begin{array}{l}\text { Caspase dependent } \\
\text { apoptosis in murine and } \\
\text { human macrophages }{ }^{17}\end{array}$ \\
\hline \multirow[t]{2}{*}{ esxA } & esat-6 & $\begin{array}{l}\text { Rv3875/Mb3905 } \\
(100 \%)\end{array}$ & 9.90 & $\begin{array}{l}\text { Antigenic secretory protein with } \\
\text { unknown function. }\end{array}$ & Apoptosis by ER stress ${ }^{18}$ \\
\hline & \multicolumn{5}{|c|}{$\begin{array}{l}\mathrm{NA}=\text { Not associated to apoptosis in monocytes or macrophages. } \\
\text { Mtb= Mycobacterium tuberculosis, Mb= Mycobacterium bovis } \\
\text { *Identity percentage according to the Protein BLAST Alignment. }\end{array}$} \\
\hline
\end{tabular}

and a RPMI-1640 medium was added with 12\% autologous serum. Monocytes were kept under the described conditions for a further 12 days. Cell viability was assessed by Trypan blue staining following recovery and before each trial. Experiments were performed with 95\% cell viability.

\section{Apoptosis induction in macrophages}

For apoptosis induction, bovine macrophages were plated in Teflon flasks, using a cell density of $4 \times 10^{5}$ cells. Twenty-four hours after seeding, cells were incubated with $100 \mu \mathrm{g} / \mathrm{ml}$ of either SE or CFE proteins for 16 hours. Apoptosis induction was also assessed with several M. tuberculosis recombinant proteins $(10 \mu \mathrm{g} / \mathrm{ml}$, Table 1) under the same culture conditions. Camptothecin $(25 \mu \mathrm{g} / \mathrm{ml})$ was employed as a positive control (Sigma Aldrich). Basal apoptosis was measured in non-stimulated macrophages. Cells were fixed after the incubation period with 1\% paraformalde- 
hyde at $4{ }^{\circ} \mathrm{C}$ for 15 minutes. They were then washed twice with $1 \mathrm{ml}$ of PBS- $1 \mathrm{x}$ and stored in a $70 \%$ ethanol solution at $-20^{\circ} \mathrm{C}$ until the DNA fragmentation analysis.

\section{DNA fragmentation}

DNA fragmentation was determined by the TUNEL technique, using the APO$\mathrm{BrdU}^{\mathrm{TM}}$ (Invitrogen) commercial kit following the manufacturer's specifications as previously described. ${ }^{10,14}$ Cells were stained in presence or absence of terminal deoxynucleotidyl transferase (TdT) as control for assay specificity. Fluorescein isothiocyanate (FITC) labeling was used to identify DNA fragmentation with a total of $10^{4}$ cells registered per assay with the flow cytometer (Facs Aria III, BD). Data were analyzed using the Infinicyt ${ }^{\mathrm{TM}}$ Flow Cytometry Software 1.7 version. Camptothecin-treated macrophages were used as a positive control for apoptotic features, whereas non-stimulated macrophages were used as negative controls. Values are represented as the mean \pm SE of three independent assays.

\section{Caspase 3 activity}

To determine caspase 3 activity, a total of $10^{6}$ cells were incubated for 24 hours with $100 \mu \mathrm{g} / \mathrm{ml}$ of either SE or CFE proteins, or with $10 \mu \mathrm{g} / \mathrm{ml}$ of each of the recombinant proteins. Cells were then washed with $1 \mathrm{ml}$ of $1 \mathrm{X}$ PBS and incubated at $4{ }^{\circ} \mathrm{C}$ for 15 minutes with lysis buffer $\left(10 \mathrm{mM}\right.$ Tris- $\mathrm{HCl}, 10 \mathrm{mM} \mathrm{NaH} \mathrm{PO}_{4}, 130$ $\mathrm{mM} \mathrm{NaCl}$ and Triton $\mathrm{x} 100$ at 1\%). Subsequently, $100 \mu \mathrm{l}$ of assay buffer were added (40 Mm HEPES, 20\% glycerol, 1M DDT, 10 mM AcDEVD-AM) and cells were incubated for a further 5 minutes at room temperature. Finally, emission fluorescence in the 380/430-460nm range was determined for 20 minutes using the Synergy HT Bio Tek microplate reader. Values are represented as the mean \pm SE of four independent assays.

\section{Statistical analysis}

Effect of treatments on induction of DNA fragmentation and the caspase 3 activity was assessed by ANOVA and the Tukey's multiple comparison test. The statistical program GraphPad Prism 7.0 was used.

\section{Results and discussion}

The main goal of this study was to assess the effect of Mycobacterium tuberculosis recombinant proteins, and of Mycobacterium bovis derived protein extracts on apoptosis induction in bovine macrophages. A total of $6 \mathrm{~L}$ of Mycobacterium bovis were cultured in Sauton medium to obtain $174 \mathrm{mg}$ of the soluble protein extract (SE) and $7.6 \mathrm{mg}$ of the culture filtrate protein extract (CFE). Figure 1 shows a 12\% polyacrylamide gel representative of the total proteins from both extracts. In the SE, twenty-six protein bands with molecular weights from 100 to $6 \mathrm{kDa}$ were observed, whereas 10 bands were found in the CFE, with molecular weights of proteins ranging from 80 to $6 \mathrm{kDa}$. These results are similar to previously reported data. ${ }^{15}$ 


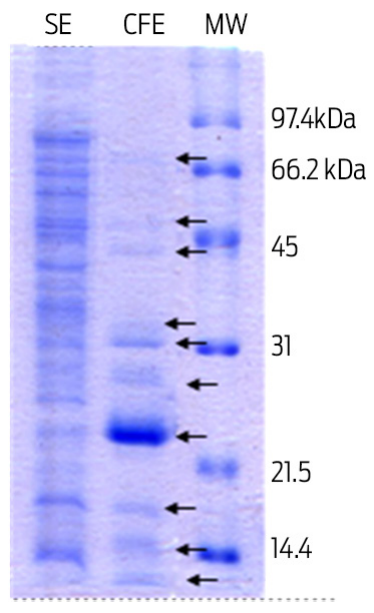

Figure 1. 12\% SDS PAGE stained with Coomassie R-250 blue, showing bands from a soluble protein extract (SE) and culture filtrate protein extract (CFE) derived from a M. bovis AN5 culture. A total of $20 \mu \mathrm{g}$ and $10 \mu \mathrm{g}$ of protein were analyzed from the SE and the CFE respectively. MW: low-range Bio-Rad molecular weight.

Induction of apoptosis in bovine macrophages was evaluated with $100 \mu \mathrm{g}$ of total proteins from extracts (SE and CFE) derived from M. bovis. Percentage of DNA fragmented cells after incubation with each protein extract is shown in Figure 2A. CFE and SE prompted DNA fragmentation in $14.11 \pm 4.15 \%$ and $26.05 \pm 4.49 \%$ of cells respectively. DNA fragmentation was observed in $4.04 \pm 4.29 \%$ of control cells. Induced apoptosis by both protein extracts was shown to be caspase 3 independent (Figure 2B).

The culture filtrate protein extract is usually enriched with secretion proteins, where the most abundant are the Ag85, MPT64 and ESAT-6 family proteins. For the soluble extract, it is possible to find both cytosolic and membrane proteins, depending on the separation method used. ${ }^{16}$ We intend to identify specific proteins from extracts in subsequent studies.

Few factors capable of triggering apoptosis have been identified in mycobacteria thus far, from which some examples are the $\mathrm{LpqH}_{1}{ }^{17}$ Esat-6, ${ }^{18}$ PE-PGR33, ${ }^{19}$ PstS- $1^{20}$ and $\mathrm{HbhA}^{21}$ proteins. We evaluated a panel of 13 recombinant M. tuberculosis proteins with known functions and molecular weights in apoptosis induction in bovine macrophages (Table 1). All proteins induced DNA fragmentation in cells, however the highest percentages of DNA fragmented bovine macrophages were found with the Hsp70 and HbhA proteins $(32.7 \pm 11.63 \%$ and $29.69 \pm 17.41$ $\%$, respectively; Figure $3 A$ ). Induced apoptosis was independent of the caspase 3 pathway (Figure 3B).

The Hsp70 protein has not been shown to elicit apoptosis in cells. It can however activate NF- $\mathrm{KB}$ through TLR-2 and TLR-4, ${ }^{22}$ to promote the synthesis of pro-inflammatory cytokines such as TNF- $\alpha^{23}$ which trigger apoptosis through the extrinsic pathway. In contrast, the HbhA protein can induce apoptosis in murine macrophages through a caspase-dependent mechanism. ${ }^{21}$ However, none of the recombinant proteins employed in this study activated caspase 3, suggesting that bovine macrophages can differentially respond to factors of mycobacterial origin. Other recombinant proteins, which are commonly described as apoptosis inducers, such as ESAT-6, PstS-1, LPqH, PE-PGRS33, marginally increased the percentage of DNA fragmented cells, but this outcome was not statistically significant. It is 

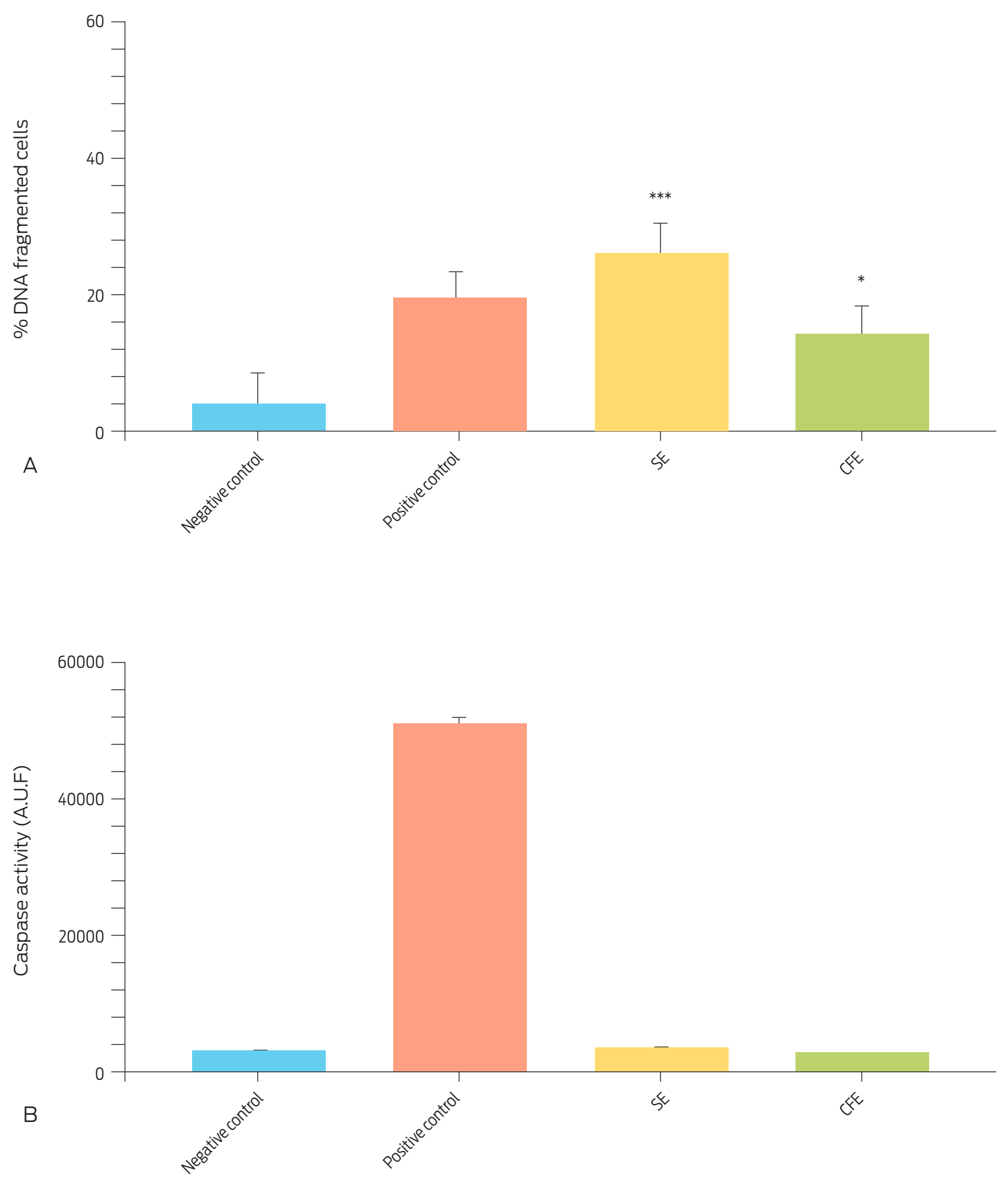

Figure 2. Percentage of DNA fragmented bovine macrophages and caspase 3 activity after incubation with $100 \mu g / \mathrm{ml}$ of M. bovis soluble protein extract (SE) or of culture filtrate protein extract (CFE) for 16 hours. Camptothecin $(20 \mu g / m l)$ was used as a positive control and RPMI as a negative control. A) DNA fragmentation was assessed by TUNEL assay. Results are expressed as the mean \pm S.E. of three independent assays. (*** $P=0.005, * P=0.0438)$. B) Caspase activity was measured through arbitrary units of fluorescence (A.U.F.) and expressed as means \pm SE of four independent assays $(P=0.0001)$. 

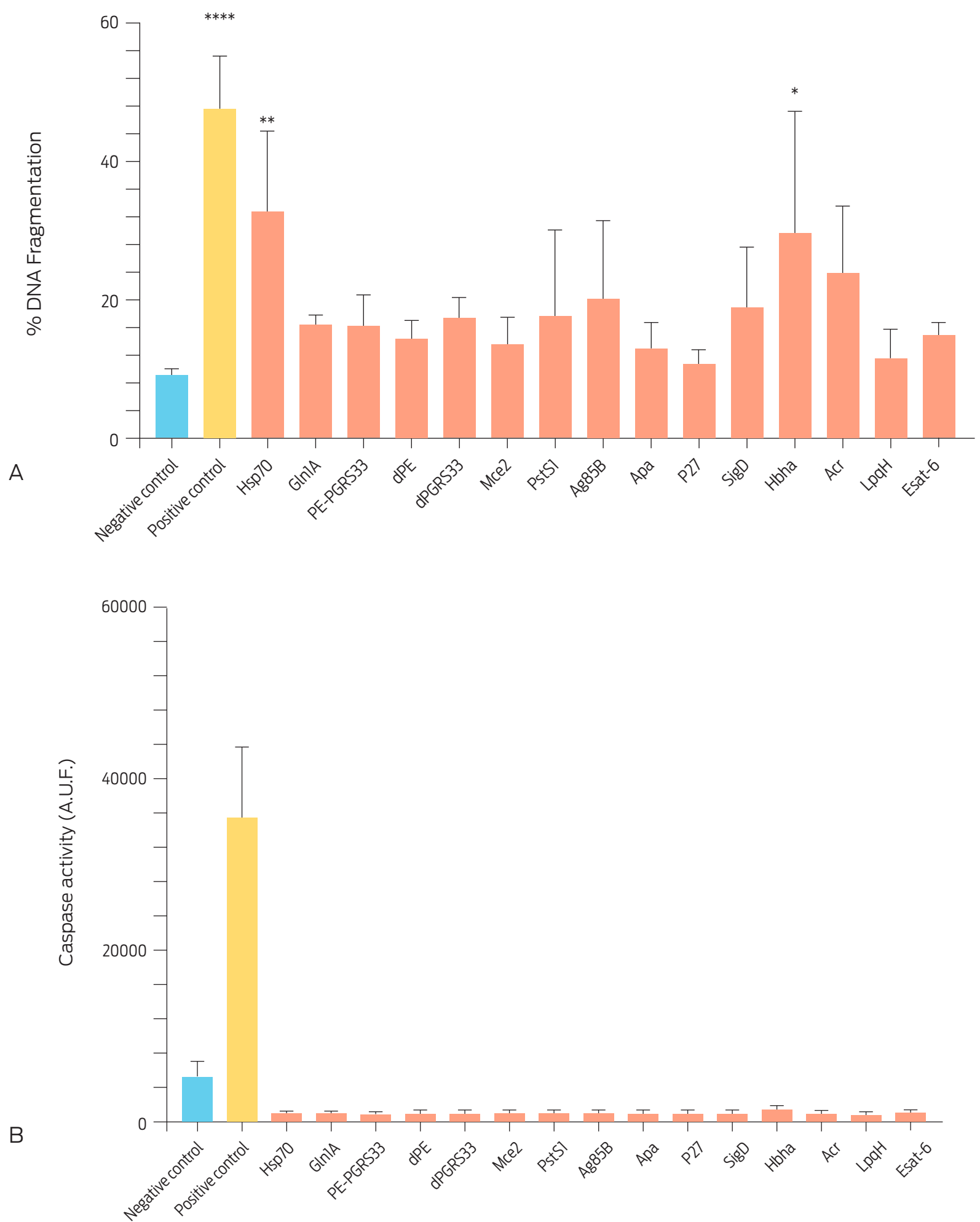

Figure 3. Percentage of DNA fragmented bovine macrophages and caspase 3 activity after culture with Mycobacterium tuberculosis complex recombinant proteins for 16 hours. A) Macrophages were incubated with $10 \mu \mathrm{g} / \mathrm{ml}$ of each protein and $20 \mu \mathrm{g} / \mathrm{ml}$ of camptothecin and RPMI as positive and negative controls, respectively. DNA fragmentation was assessed by TUNEL assay. Results are expressed as means \pm S.E of three independent assays $(P<0.05)$. B) Caspase activity was measured using arbitrary units of fluorescence (A.U.F.), in $10^{6}$ bovine macrophages incubated for 24 hours with $10 \mu \mathrm{g} / \mathrm{ml}$ of each of the recombinant proteins Data are expressed as means \pm S.E. of two independent assays with two replicas each. Recombinant proteins Ag85-B, Apa and Gln 1A were not included when analyzing caspase activity. 
not clear why apoptosis was not observed in a larger number of macrophages after incubation with these proteins as has been reported in other studies; however, specific characteristics of the used cell types could allow for different results.

Pathogenesis of mycobacteria relates to their ability to survive within macrophages and to modulate apoptosis induction of infected cells. In addition to multiplicity of infection and virulence of the mycobacterial strain, the course of an infection by the $M$. tuberculosis complex is determined by the type of triggered cell-death. 6,7,11 Apoptosis in human or mouse macrophages after Mycobacterium tuberculosis infection is normally due to caspase activation. However, when the multiplicity of infection is 25:1, macrophages undergo apoptosis independently of the caspase pathway. Bovine macrophages infected by $M$. bovis also undergo apoptosis ${ }^{12}$ independently of caspases. ${ }^{13}$ Hence, apoptotic pathway taken by the cell after infection could have important implications for disease outcome and host survival. ${ }^{6-8}$ Our main finding is that a subgroup of proteins and protein extracts from strains of the Mycobacterium tuberculosis complex were able to induce DNA fragmentation in bovine macrophages through a pathway in which caspases were not activated. This suggests that response of bovine macrophages to infection by tuberculosis bacilli differs from that seen in murine or human cells. ${ }^{16}$ We further speculate that the caspase-independent apoptosis mechanism aims to protect the organism from pathogens and is activated when the caspase pathway has failed. Mycobacteria may prevent caspase activation and thus apoptosis induction of its host cell to survive, whilst the host may trigger a caspase independent apoptosis pathway in an attempt to kill the pathogen. Our findings support the concept that apoptosis may work as a natural resistance mechanism of the host. ${ }^{14,24}$

\section{Conclusions}

Apoptosis is a host defense mechanism against mycobacterial infection that can also benefit the pathogen by eliminating host defense cells. It is thus necessary to understand the mechanisms used by bacteria to modulate apoptosis. Our data show that bovine macrophages respond differently than murine or human cells to mycobacterial infection. In addition, this is the first report of cell-death induction in bovine macrophages by two $M$. tuberculosis recombinant proteins, not previously identified as apoptotic, through a caspase independent pathway. Moreover, soluble protein (SE) and culture filtrate protein (CFE) extracts from cultured $M$. bovis also induce apoptosis through a caspase independent mechanism. This pathway had been only previously observed with high multiplicities of infection with M. tuberculosis. 


\section{Acknowledgements}

This work was supported by grants PAPIIT IN-217512, PAPIIT IN-220415 from the Universidad Nacional Autónoma de México and by grant CB 2011-167488-Z from Conacyt (Consejo Nacional de Ciencia y Tecnología). We wish to thank María Guadalupe Domínguez Macouzet for technical support on caspase 3 assays and Cristina Parada Colín for assistance with protein extract preparations.

\section{Author contributions}

A.B.G., E.A.S., J.A.G.P.: experimental design; A.M.R., I.J.V., O.C.B.: laboratory work; A.M.R., S.F.V., I.J.V., A.B.G., J.A.G.P.: data analysis; C.E.P., J.M., L.A.-P., J.A.G.P.: contributed reagents/materials/analysis tools; S.F.V., J.A.G.P.: document drafting.

\section{References}

1. Michel AL, Muller B, van Helden PD. Mycobacterium bovis at the animal-human interface: a problem, or not? Veterinary microbiology. 2010;140(3-4):371-81. Epub 2009/09/24. doi: 10.1016/j.vetmic.2009.08.029.

2. Caminiti A, Pelone F, LaTorre G, De Giusti M, Saulle R, Mannocci A, et al. Control and eradication of tuberculosis in cattle: a systematic review of economic evidence. The Veterinary record. 2016;179(3):70-5. Epub 2016/07/17. doi: $10.1136 / v r .103616$.

3. Sakamoto K. The pathology of Mycobacterium tuberculosis infection. Veterinary pathology. 2012;49(3):423-39. Epub 2012/01/21. doi: $10.1177 / 0300985811429313$.

4. Cassidy JP. The pathogenesis and pathology of bovine tuberculosis with insights from studies of tuberculosis in humans and laboratory animal models. Veterinary microbiology. 2006;1 12(2-4):151-61. Epub 2005/11/29. doi: 10.1016/j. vetmic.2005.11.031.

5. Rohde K, Yates RM, Purdy GE, Russell DG. Mycobacterium tuberculosis and the environment within the phagosome. Immunological reviews. 2007;219:37-54. Epub 2007/09/14. doi: 10.1111/j.1600-065X.2007.00547.x.

6. Molloy A, Laochumroonvorapong P, Kaplan G. Apoptosis, but not necrosis, of infected monocytes is coupled with killing of intracellular bacillus Calmette-Guerin. The Journal of experimental medicine. 1994;180(4):1499-509. Epub 1994/10/01.

7. Behar SM, Martin CJ, Booty MG, Nishimura T, Zhao X, Gan HX, et al. Apoptosis is an innate defense function of macrophages against Mycobacterium tuberculosis. Mucosal immunology. 2011;4(3):279-87. Epub 2011/02/11. doi: 10.1038/mi.2011.3.

8. Lee J, Hartman M, Kornfeld H. Macrophage Apoptosis in Tuberculosis. Yonsei Medical Journal. 2009;50(1):1-11. doi: 10.3349/ymj.2009.50.1.1.

9. Wu H, Che X, Zheng Q, Wu A, Pan K, Shao A, et al. Caspases: a molecular switch node in the crosstalk between autophagy and apoptosis. International journal of biological sciences. 2014;10(9):1072-83. Epub 2014/10/07. doi: 10.7150/ ijbs.9719.

10. Esquivel-Solis H, Vallecillo AJ, Benitez-Guzman A, Adams LG, Lopez-Vidal Y, Gutierrez-Pabello JA. Nitric oxide not apoptosis mediates differential killing of Mycobacterium bovis in bovine macrophages. PloS one. 2013;8(5):e63464. Epub 2013/05/22. doi: 10.1371/journal.pone.0063464. 
11. Divangahi M, Behar SM, Remold H. Dying to live: how the death modality of the infected macrophage affects immunity to tuberculosis. Advances in experimental medicine and biology. 2013;783:103-20. Epub 2013/03/08. doi: 10.1007/978-1-4614-6111-1_6.

12. Chen M, Gan H, Remold HG. A mechanism of virulence: virulent Mycobacterium tuberculosis strain H37Rv, but not attenuated H37Ra, causes significant mitochondrial inner membrane disruption in macrophages leading to necrosis. Journal of immunology (Baltimore, Md : 1950). 2006;176(6):3707-16. Epub 2006/03/07.

13. Gutierrez-Pabello JA, McMurray DN, Adams LG. Upregulation of thymosin beta10 by Mycobacterium bovis infection of bovine macrophages is associated with apoptosis. Infection and immunity. 2002;70(4):2121-7. Epub 2002/03/16.

14. Vega-Manriquez X, Lopez-Vidal Y, Moran J, Adams LG, Gutierrez-Pabello JA. Apoptosis-inducing factor participation in bovine macrophage Mycobacterium bovis-induced caspase-independent cell death. Infection and immunity. 2007;75(3):1223-8. Epub 2006/12/13. doi: 10.1128/iai.01047-06.

15. Fifis T, Costopoulos C, Radford AJ, Bacic A, Wood PR. Purification and characterization of major antigens from a Mycobacterium bovis culture filtrate. Infection and immunity. 1991;59(3):800-7.

16. Flores-Villalva S, Rogriguez-Hernandez E, Rubio-Venegas Y, Canto-Alarcon JG, Milian-Suazo F. What Can Proteomics Tell Us about Tuberculosis? Journal of microbiology and biotechnology. 2015;25(8):1181-94. Epub 2015/03/05. doi: 10.4014/jmb.1502.02008.

17. Ciaramella A, Martino A, Cicconi R, Colizzi V, Fraziano M. Mycobacterial 19-kDa lipoprotein mediates Mycobacterium tuberculosis-induced apoptosis in monocytes/macrophages at early stages of infection. Cell death and differentiation. 2000;7(12):1270-2. Epub 2001/03/29. doi: 10.1038/sj.cdd.4400761.

18. Choi HH, Shin DM, Kang G, Kim KH, Park JB, Hur GM, et al. Endoplasmic reticulum stress response is involved in Mycobacterium tuberculosis protein ESAT-6-mediated apoptosis. FEBS letters. 2010;584(11):2445-54. Epub 2010/04/27. doi: 10.1016/j.febslet.2010.04.050.

19. Basu S, Pathak SK, Banerjee A, Pathak S, Bhattacharyya A, Yang Z, et al. Execution of macrophage apoptosis by PE_PGRS33 of Mycobacterium tuberculosis is mediated by Toll-like receptor 2-dependent release of tumor necrosis factor-alpha. The Journal of biological chemistry. 2007;282(2):1039-50. Epub 2006/11/11. doi: 10.1074/jbc.M604379200.

20. Sanchez A, Espinosa P, Esparza MA, Colon M, Bernal G, Mancilla R. Mycobacterium tuberculosis 38-kDa lipoprotein is apoptogenic for human monocyte-derived macrophages. Scandinavian journal of immunology. 2009;69(1):20-8. Epub 2009/01/15. doi: 10.1111/j.1365-3083.2008.02193.x.

21. Sohn H, Kim JS, Shin SJ, Kim K, Won CJ, Kim WS, et al. Targeting of Mycobacterium tuberculosis heparin-binding hemagglutinin to mitochondria in macrophages. PLoS pathogens. 2011;7(12):e1002435. Epub 2011/12/17. doi: 10.1371/journal.ppat. 1002435.

22. Bulut Y, Michelsen KS, Hayrapetian L, Naiki Y, Spallek R, Singh M, et al. Mycobacterium tuberculosis heat shock proteins use diverse Toll-like receptor pathways to activate pro-inflammatory signals. The Journal of biological chemistry. 2005;280(22):20961-7. Epub 2005/04/06. doi: 10.1074/jbc.M41 1379200. 
23. Anand PK, Anand E, Bleck CK, Anes E, Griffiths G. Exosomal Hsp70 induces a pro-inflammatory response to foreign particles including mycobacteria. PloS one. 2010;5(4):e10136. Epub 2010/04/21. doi: 10.1371/journal.pone.0010136.

24. Broker LE, Kruyt FA, Giaccone G. Cell death independent of caspases: a review. Clinical cancer research : an official journal of the American Association for Cancer Research. 2005;11(9):3155-62. Epub 2005/05/04. doi: 10.1158/10780432.ccr-04-2223. 